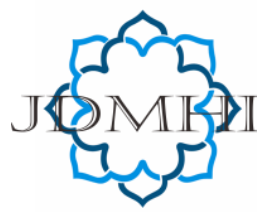

email: jdmhi@walisongo.ac.id

Journal of Digital Marketing and Halal Industry

ISSN: 2716-4810 (print) ISSN: 2716-4802 (online)

\title{
Analysis of Factors influencing the Purchasing Decision of Facial Foam labeled Halal
}

\section{Hesti Hanan Nadhifah ${ }^{1}$, Hendri Hermawan Adinugraha ${ }^{2}$}

${ }^{1}$ Faculty of Economics and Business, Dian Nuswantoro University Semarang, Indonesia

${ }^{2}$ Faculty of Islamic Economics and Business, Islamic State Institute of Pekalongan, Indonesia

\section{A R T I C L E I N F O}

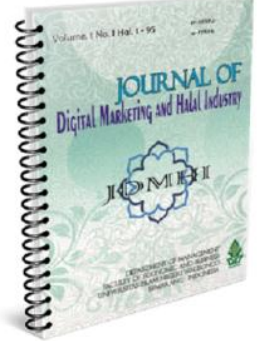

Article history:

Received 26 February 2020

Accepted 04 July 2020

Published 10 July 2020

Keywords:

Price, Quality, Product Design, Brand Image, Decision to

Purchase.

\section{A B S T R A C T}

Consumers in deciding the purchase are motivated by various factors. The purpose of this study is to analyze the effect of price, product quality, product design, and brand image on purchasing decisions. The type of data used is primary data, using equestionnaires. The sampling technique uses purposive sampling. The analysis technique uses multiple regression. The analysis shows that the price has a positive and significant effect on purchasing decisions. Product quality has a positive and significant influence on purchasing decisions. Product design has a positive and significant effect on purchasing decisions. Brand image has a positive and significant influence on purchasing decisions. In the future, the company needs to set prices following the purchasing power of the people but still maintain product quality and pay attention to product design.

@2020 Journal of Digital Marketing and Halal Industry

\section{Introduction}

Competition in the cosmetic industry today is very strict with the presence of diverse creative products. How to survive in the cosmetic industry is with still has the creativity and produces the products and innovation. The very rapid development of the course resulted in more competition among the actors in the business (Munggaran, 2015). Someone needs a cosmetic because to protect the skin from various outside influences, such as sun, dust, pollution, and other so on when this cosmetic

\footnotetext{
* Corresponding author.email: hendri.hermawan@iainpekalongan.ac.id DOI: http://dx.doi.org/10.21580/jdmhi.2020.2.1.5283
} 
is required by most of the people, especially women, although men sometimes there is also a need cosmetics to keep the appearance because of the work-related with the crowd (Tarigan, 2016).
Indonesia has produced facial soap cleansers from various manufacturers and brands. Based on the data market share category facial cleansing soap years 2016 - 2018, then it can be aware of rank, namely :

\section{Tabel 1}

\section{Market Share Facial Cleansing Soap}

Year 2016-2018

\begin{tabular}{lllllll}
\hline No. & 2016 & & 2017 & \multicolumn{3}{c}{2018} \\
& Brand & $\%$ & Brand & $\%$ & Brand & $\%$ \\
\hline 1 & Pond's & 40,6 & Pond's & 40,0 & Pond's & 29,3 \\
2 & Biore & 21,2 & Biore & 21,5 & Biore & 19,2 \\
3 & Garnier & 9,1 & Garnier & 9,4 & Garnier & 16,8 \\
\hline \multicolumn{3}{l}{ Source: //www.topbrand-award.com/top-brand-survey/ } \\
\hline
\end{tabular}

Table 1.1 shows that the market share soap cleaning the face of the 2016 - 2018, brand Pond's occupy ranked first. Market share demonstrates mastery of the broad market or the highest margin sales in the market, meaning that the higher the market share, the higher the consumer purchase decision (Buchari Alma, 2013). However, from the years 2016 - 2018, market shares tend to fall, i.e., from to $40.6 \%$ in 2016 , be of $40 \%$ year 2017 even decreased to $29.3 \%$ of the year 2018. It is indicated that the tendency to decrease market share show that purchase decision is getting down.

Seen of the three competitors products Pond's, Biore, and Garnier experience the increase from 2015 - 2017, so as not analyzed because consumer purchase decisions are already good show that product is also better. Therefore, this study intends to research cleaning soap brand Pond's.

The decision the purchase was the decision that made individuals use resources they have available to consume (Daryanto, 2013). Consumers many make purchase decisions every day (Fataron \& Rohmah, 2020). Large companies are researching the purchasing decisions of consumers in detail to be able to answer question-questions: what, where, how, how much, when, and why they buy. Marketers can teach the purchasing consumer to answer the question: what, where, and how much they buy, but learn about why the behavior the purchase the consumer is not too easy (Ginting, 2012).

Many factors can affect the purchase decision. According To (Erviana, 2014), (Achidah, Nur, 2016), (Tengor, Gloria, 2016) as well as (Muhtarom, 2018), the factors that can affect the decision of purchase is a price, quality, product design, and brand image. The research also supported by some other researchers such as (Habibah, 2016), (Puspita, Diestutiace Lucky, 2016), (Tarigan, 2016) as well as (Ansah, 2017). However, in the study (Martini, 2015) and (Imelda, Sri, 2016) shows a different result than the price and quality of 
the product is not influence on purchase decisions. Based on background and research gap in above, then researchers interested in examining the factors that affect the decision consumer purchase facial foam Pond's has been certified halal in Semarang

\section{Literature Review}

Definition of marketing, according to (Kotler, 1997) is a social and managerial process in which individuals and groups get what they need and want by creating, offering, and exchanging products with other parties. The definition of Marketing according to Harper W (2000: 4) that Marketing is "A social process involving important activities that enable individuals and companies to get what they need and want through exchanges with other parties and to develop exchange relationships. "The definition of marketing mix according to (Swastha, 2002) that Marketing Mix is "a combination of four variables of activities that are the core of the company's marketing system, namely products, price structures, promotional activities, and distribution systems.

\section{Buying Decision}

The decision purchase is to buy a brand the most desired consumers (Ginting, 2012). Another concept of the purchase decision is a decision that made individuals use their resources that have been available to consume an item (Daryanto, 2013). Description of other purchase decisions is the decision taken individuals because of the stimuli (the stimuli), both that comes from outside the individual and the things that are on the individual himself (Paul \& Olson, 2013). Retrieval consumer decision is the process of receiving and evaluating brand information product specific. There are two factors that affect decision-making, which will then determine the response of the consumer. The first is the consumer itself, and the second are environmental factors (Suryani, 2013).

Companies understand how consumer decisions will respond to a variety of figure products, prices, and stimulation of advertising that has the advantages of its competitors. Consumers will receive stimulation and give us your feedback (Ginting, 2012). The stimuli (stimulus) marketing consists of product, price, promotion, and distribution. As for the incentives, another belonging to the strength and important events in the environment, consumers economical, technological, political, and cultural. All this input entered in the consumer's mind, where all change to be response buyers look product choice, brand choice, when purchase, and the number of purchases (Ginting, 2012). Marketers want to understand how the stimuli changed to responses in the minds of the buyer, which consists of two parts. First, the characteristics of the buyer that causes the consumer to apply receive and react to stimuli. Second, the process of that decision owns that affect the buyer (Ginting, 2012).

\section{Price}

Price is the amount of money that must be paid by the consumer to forget the product (Ginting, 2012). The definition of other price is the value of the goods declared with the money (Ginting, 2012). Another meaning price is the number of money in pay for a product, or some values are interchangeable consumers for the benefits of having or using the product (Buchari Alma, 2013). Another meaning price is the number of money in play for a product, or several values are interchangeable consumers for the benefits of 
having or using the product (Daryanto, 2013). Other concepts price is a unit of monetary or other sizes exchanged in order to obtain the right of ownership or use of a goods or services (Tjiptono, 2015).

Price it is the only element in the marketing mix generate income. Price is also an element of the mix marketing the most easy customized. In addition, the price also communicates the value of the company's products against the market (Widiyono dan Mukhaer Pakkanna, 2013).

The determination of the the price is one of the most important decision in marketing. The price is the only element of the marketing mix that income or revenue for the company, while the third of the other elements (product, distribution, and promotion) leads to onset the cost (expenditure). In addition, price is an element of the marketing mix besifat flexible, meaning that it can be changed quickly. Different is the case with the characteristics of the product or commitment to the distribution channel. Both of the latter can not modified/adjusted easily and quickly, because usually it concerns long-term decisions (Tjiptono, 2015).

Price not just the numbers on the price tag. Price has a lot of forms and carry out many functions. Throughout history, the price set through negotiations between the buyer and the seller. Fresh bid is still often performed in several fields. Set one the price for all buyers is the idea of a relatively modern embossed with the development of the retail trade large scale at the end of the century nineteenth (Kotler, 2014).
Practices pricing has undergone major changes in the years last. Many companies counteract the tendency of a low price and successfully encourage consumers to purchase products and services more expensive by combining the formulation of a unique product that involves marketing campaign (Kotler, 2014).

The decision the purchase is based on how consumers perceive prices and some of the prices the actual current to be considered is not the price otherwise marketers. Consumers may have a lower limit price in where the price is lower than the limit that signifies quality bad or quality is not acceptable, and also the upper limit price where the price is higher than the limit it is considered too excessive and not worth the money spent (Kotler, 2014).

\section{Quality Product}

Quality the product is the ability of a product to the displayed function (Ginting, 2012). Another definition of product quality is the ability products to carry out its functions (Daryanto, 2013). Understanding another quality product is the totality of features and characteristics of products or services that rely on its ability to satisfy stated needs or implied (Kotler, 2014).

Quality products regarding the general resistance of the product, reliability, precision, ease of operation and repair as well as the attribute value other. Although some of these attributes are measurable, but of the view of marketers, the quality of the products must be measured with the perception of the buyer. Companies rarely want to try it or able to offers a level of quality product that is probably the most high (Ginting, 2012). 
Quality the product should also be determined by the way consumers perceive product the. From a marketing standpoint, quality is the ability of the product to satisfy the needs or desires of consumers. This definition focuses on consumers and how the consumer thinks a product will fulfill the purpose of the certain (Ginting, 2012).

In outside levels the quality of the product, the high quality also means submission consistent above the level of the quality target to the consumers. In this sense, the quality of the product means without damage and the variation. All the company must seek a high level of consistency quality (Ginting, 2012).

Company-company change the quality of the product becomes a weapons strategy that potential. Quality strategy quality is the improvement of the quality of a little over competitors by consistently presenting products and services to better serve the needs and preferences of consumers on the quality of the product (Ginting, 2012).

The provision of the right product on time, in place and in the desired way the consumer is a challenge. This is true, whether the product such is the services the main, main item, or as usual, a mix between both. Marketing managers must think about the overall products. Products provided as well as ensuring that all elements of the has been aligned in the marketing strategy. Sometimes, a product not enough to meet the needs of the target consumers. Therefore, it is necessary to mix with other products (Ginting, 2012).

Companies that are not able to create the new product will face the risk of such a decrease in the volume of sale, because the emergence of a competitor who is creative, a change in consumer tastes, the emergence of new technologies in the production process (Ginting, 2012).

The idea about the product as excellence or satisfaction that the potential for the consumer is very important. Many business managers to focus too much on a technical detail in producing a product. On the other hand, many consumers are think of about products in terms of the total benefits that it offers. Satisfaction the may be in the form of deals total product which is a blend between the good service, interesting physical features that accordingly, a useful guide, packaging neat, warranty can be trusted, and even the brand easy to remember (Ginting, 2012).

\section{Design}

Design the product is the overall appearance of the product which compare one product with other products (Ginting, 2012). Another definition design the product is the process of designing the style and functionality of the product attractive, easy, safe and not expensive to use and serviceable, as well as simple and economical to be made and distributed (Daryanto, 2013: 54). The concept of other design product is the totality of features affect the look, feel, and functionality of the product based on the needs of consumers (Kotler, 2014).

Opinion on the good design is very convincing especially for the company's products consumers who are more small companies and beginners who do not have the advertising budget is large (Kotler, 2014).

Design more than just the outer skin, the design is at the heart of the product. Design well not only has contributed in the appearance of the product but also in manfaathis. Good design is judged by the understanding deep about the needs of the 
customer. More than just creating the attribute products or services, the design involving the formation of experience the use of the product for the customer. Therefore, the design of the product you should not think too much about product attributes and specifications technical think of how customers use and benefit from the product (Kotler, 2014)

\section{Image Brand}

Image brand is the impression obtained in accordance with the knowledge and the understanding of someone about something (Buchari Alma, 2013). The other definitions of brand image is the perception and attitude of consumers towards the brand based on what received and perceived by the consumers (Peter, 2013). Another concept image brand is everything associated with the brand in the minds of the consumer or the impression consumer about a brand (Suryani, 2013).

Image has a major role in influencing the decision-making consumers. When consumers do not have complete information about the product, then the consumer will use brand image as the basis of choosing a product (Suryani, 2013). Image is the perception consumers towards the brand thoroughly is formed by the information received and the consumer experience of the brand. What appears when consumers were asked about the image of a brand, then the consumer will reveal the impression and belief brand specific (Suryani, 2013).

Consumers in general have a positive perception towards the brand pioneer (the first brand in a product category), even though the brand the next appears. After that also there is a positive correlation between the brand image of pioneer with the image of the ideal self of the individual. Perception positive towards the brand pioneer, this will lead to the intention purchase a positive (Suryani, 2013).

A the image of a strong brand has a wealth of brand high, because consumers have brand loyalty, high awareness of name, quality received, trademark, and relationship distribution. A brand with a strong image is a valuable asset (Ginting, 2012).

Marketers have to manage the brand carefully in order to maintain the image of the brand. Marketers must develop a strategy that efficient to maintain and even increase brand awareness, acceptance quality and the usefulness of brand and brand associations are positive all the time. It this requires investment in research and development continuously, advertising is dodgy and the service of the commercial and the consumer a great (Ginting, 2012). Brand name tell buyers regarding the quality of the product. Buyers always buy the same brand because knowing that will obtain the same quality each times buy (Ginting, 2012: 103).

\section{Method, Data, and Analysis}

Research this is a type of quantitative research. The population this study is a consumer-soap facial cleanser Pond's in Semarang that the amount is not known because every day there are fluctuations obtained from Google Form. Sample in this study, is the most consumers soap facial cleanser Pond's in Semarang obtained from Google Form. Because the number of the population is not known then the number of 
samples searched by the formula Isac Michel (Siregar, 2013). In research is the source of the data comes from a questionnaire given to 100 respondents, then from the results statement were analyzed.

Methods data collection used was a questionnaire or questionnaires. The questionnaire is a technique of collecting data by providing or distribute a list of questions/questions to the respondents with hope written answers (Arikunto, 2013). List the question/statement can be open if the answer is no determined previous, while is closed if alternative answers have been provided. Instruments in the form of sheet of a list of questions can be in the form of a questionnaire (questionnaire), checklist or scale.
Techniques the analysis in this study is Multiple Regression Analysis. Regression multiple used to measure the strength of the relationship between the two or more variables, also shows the direction of relationship between variables the dependent with the independent variable (Ghozali, 2012). Metode regresi berganda ini dikembangkan untuk mengestimasi nilai variabel dependen (Y) dengan menggunakan lebih dari satu variabel independen (X). The method of multiple regression is developed to estimate the value of the dependent variable (Y) by using more than one variable independent $(\mathrm{X})$.

\section{Result and Discussion}

Table 2. Results Regression

\begin{tabular}{|c|c|c|c|c|c|}
\hline Model & $\begin{array}{l}\text { Unst: } \\
\text { Coeft } \\
\text { B }\end{array}$ & $\begin{array}{l}\text { ndardized } \\
\text { icients } \\
\text { Std. Error }\end{array}$ & $\begin{array}{l}\text { Standardized } \\
\text { Coefficients } \\
\text { Beta }\end{array}$ & $\mathrm{t}$ & Sig. \\
\hline (Constant) & ,989 & ,699 & & 1,415 & 160 \\
\hline Harga & ,236 & 112 & ,205 & 2,114 & ,037 \\
\hline $\begin{array}{l}\text { Kualitas } \\
\text { Produk }\end{array}$ & ,439 & , 143 & ,283 & 3,060 & ,003 \\
\hline $\begin{array}{l}\text { Desain } \\
\text { Produk }\end{array}$ & ,367 & , 167 & ,228 & 2,199 & ,030 \\
\hline Citra Merek & ,408 & , 161 &, 254 & 2,528 & ,013 \\
\hline
\end{tabular}

a. Dependent Variable: Purchase Decision

Source : Primary Data Processed, Year 2020.

Based on from the results of the multiple regression obtained, it can be made of linear equations as follows :

$\mathrm{Y}=0,989+0,236 \mathrm{X} 1+0,439 \mathrm{X} 2+0,367$

$\mathrm{X} 3+0,408 \mathrm{X} 4$
The equation such a regression can be interpreted as follows :

1. Constants $(\alpha)$ at $=0,989$, this means that if price, the quality of the product, product design, and brand image in the state of zero then the decision purchase tend to positive. But because it is not 
significant then there is no increase in purchase decisions soap facial cleanser Pond's before affected variables price, the quality of the product, product design, and brand image.

2. Coefficient regression price $(\mathrm{b} 1)=0,236$, the value of the positive that is there is every price tools, it will increase the purchasing decision.

3. Coefficient the regression of the quality of the product $(\mathrm{b} 2)=0,439$, the value of the positive that is there is every increase the quality of the product, it will increase the purchasing decision.

4. Coefficient regression of product design (b3) $=0,367$, the value of the positive that is there is every improved product design, then it will improve the decision of the purchase.

5. Coefficient regression of brand image (b4) $=0,408$, this means that every there is an increased brand image, it will increase the the decision of the purchase.

\section{Uji Model}

Test the model is used to see whether or not the regression model on this study. Testing using the coefficient of determination and test $-\mathrm{F}$.

\section{a. Coefficient Determination}

b. Coefficient determination used to see the ability of the variable price, the quality of the product, product design, and brand image in describes the purchase decision. The results of the coefficient of determination can be seen in the table Three the following:

Table 3. Results The Coefficient Of Determination Model Summary ${ }^{\mathrm{b}}$

\begin{tabular}{|c|c|c|c|c|}
\hline Model & $\mathrm{R}$ & R Square & $\begin{array}{l}\text { Adjusted } \\
\text { R Square }\end{array}$ & $\begin{array}{l}\text { Std. Error of the } \\
\text { Estimate }\end{array}$ \\
\hline 1 &, $921^{\mathrm{a}}$ & ,848 &, 841 & 1,520 \\
\hline
\end{tabular}

Source : Primary Data Processed, Year 2020

The magnitude of the the coefficient of determination can be seen in the Adjusted $R$ Square by 0,841 , that is price, product quality, product design, and brand image able to explain the decision of the purchase of 84,1 $\%(0,841 \times 100 \%)$, whereas by $15,9 \%$ ( $100 \%$ $84,1 \%$ ) the purchase decision is explained by other variables outside of price, the quality of the product, product design, and brand image.

\section{Uji - F}

Test - F used to test the regression model between variable price, the quality of the product, product design, and brand image against purchase decision. Testing is done based on the significance value i.e. if the 
obtained value sig. smaller $(<) 0.05$ then be seen in table 4 the following: model regression accepted. Results test - F can

Table 4. Results Test - F

\begin{tabular}{|c|c|c|c|c|c|}
\hline ANOVA $^{a}$ & & & & & \\
\hline Model & $\begin{array}{l}\text { Sum of } \\
\text { Squares }\end{array}$ & $\mathrm{df}$ & $\begin{array}{l}\text { Mean } \\
\text { Square }\end{array}$ & $\mathrm{F}$ & Sig. \\
\hline Regression & 1221,293 & 4 & 305,323 & 132,074 &, $000^{b}$ \\
\hline Residual & 219,617 & 95 & 2,312 & & \\
\hline Total & 1440,910 & 99 & & & \\
\hline $\begin{array}{l}\text { a. Dependen } \\
\text { b. Predictors } \\
\text { Product Desig }\end{array}$ & $\begin{array}{l}\text { Variable: } \mathrm{Pu} \\
\text { (Constant), }\end{array}$ & $\begin{array}{l}\text { chase } \\
\text { Bran }\end{array}$ & $\begin{array}{l}\text { ecision } \\
\text { Image, } P\end{array}$ & luct Quali & Price, \\
\hline
\end{tabular}

Results test - F of 132,074 with a sig of 0.000 is smaller $(<)$ 0.05, which means price, product quality, product design and brand image effect on purchase decisions simultaneously so that the regression model accepted.

\section{Testing Hypothesis}

Testing the hypothesis in this research can be done from the results of the test $-t$, which is used for prove the existence of influence between variable price, the quality of the product, product design, and brand image against purchase decision partial. Testing is done based on the significance value i.e. if the obtained value sig. smaller $(<) 0.05$ then the hypothesis is accepted. Results $t$ - test can be seen in table 5 .

Table 5. Results T - test

\begin{tabular}{lll}
\hline Model & $\mathrm{t}$ & Sig. \\
& & \\
\hline (Constant) & 1,415 &, 160 \\
Harga & 2,114 &, 037 \\
Kualitas Produk & 3,060 &, 003 \\
Desain Produk & 2,199 &, 030 \\
Citra Merek & 2,528 &, 013 \\
\hline
\end{tabular}

a. Dependent Variable: Purchase Decision

Source : Data Primary Processed, 20 Years 20.

http://iournal.walisongo.ac.id/index.php/JDMHI/index DOI: http://dx.doi.org/10.21580/jdmhi.2020.2.1.5283 
Based on from the results of $\mathrm{t}$ - test, then it can be done proof as the following :

1. Results test - t prices by 2,114 with sig 0,037 smaller $(<) 0.05$ means accept the hypothesis that the stated prices influence the purchase decision.

2. Results $t$ - test the quality of the product by 3,060 with sig 0,003 smaller $(<) 0.05$ means accept the hypothesis that stated the quality of the product influence the decision purchase.

3. Results $t$ - test of product design of 2,199 with sig 0,030 smaller (<) 0.05 means accept the hypothesis that stated the design of the product influence the decision purchase.

4. Results $t$ - test of brand image by 2,528 with sig 0,013 smaller (<) 0.05 means accept the hypothesis that stated image of the brand effect against the decision of the purchase.

\section{The influence of Price Against The Decision Of The Purchase Facial Foam Pond's in Semarang}

Test hypothesis proves that the price has positive and significant effect against the decision of the purchase, with the results obtained from the $\mathrm{t}$ - test by 2,114 and sig. $0,037<0,05$. These results can be interpreted more according to the price offered then will further improve the consumer buying decision against soap facial cleanser Pond's. Price is the value of an item that is expressed with money (Buchari Alma, 2013). Consumers will consider the price of a products with the financial condition of the possessed, i.e. if the condition the financial enough to reach the price offered then they can make purchasing decisions.

As comparison to the specifications of the products are almost the same, namely whitening for Pond's White Beauty Micellar Water $100 \mathrm{ml}$ size is offered at a range of $\mathrm{Rp}$ 28.500, while for other brands that Garnier Sakura White Pinkish Radiance Facial Foam Cleanser $100 \mathrm{ml}$ is offered for the price $\mathrm{Rp}$ 23.000, so there is still enough there is a difference with the price of other brands. This makes the consumer still needs a lot of consideration if you want to continue to do purchase soap pemberih face Pond's, because the price is still less compete with the price of other brands.

Consumers himself gave a high appraisal to the price of harga soap facial cleanser Pond's according to the perceived benefits on the face (the value of the average 3,46). This shows that the price offered in accordance with the benefits provided for example with make a purchase Pond's Facial Foam White Beauty for Rp 28.800 but can be beneficial for the face, namely the face always looks clean and moist free oil and always look white and clean throughout the day. It this can increase the attractiveness of the appearance so that it becomes consideration of consumer to make a purchase. Consumers also give high ratings for harga soap facial cleanser Pond's according to the quality of its products (the value of the average is 3.45), as for the high end variant that is Pond's Instabgriht Tone Up offered at a price range of $\mathrm{Rp} 40.000$ in accordance with the usage of quality material selection such as using vitamin $\mathrm{B} 3+$ which serves to rejuvenate the skin, protect UV rays and inflammation of 
the skin, and using milk protein essence that serves to cleanse the skin cells with nutrients clear up the facial skin so the original skin tone brighter. With the price of a comparable quality material then it will give benefits is maximum and it is safe to use, so it is that can attract the interest of consumers to make a purchase soap facial cleanser Pond's.

Based on from the perception given by the consumer then the for the price need offered in a range that is affordable as with give a price discount for consumers who make a purchase in some stores partner sales both online stores and offline so with the discount, the prices become cheaper and consumers will be more willing to do the purchase soap facial cleanser Pond's. Another thing that needs to be done in terms of prices is to apply price compete with the prices that are fixed but give volume or the contents of the packaging more than the brand competitors, so the the price is expensive but consumers can get the content more and could certainly be used in the long term. This could save even more because not often do purchase. This factor which will attract the desire of consumers to make a purchase soap facial cleanser Pond's.

Results the study supports research (Martini, 2015), (Achidah, Nur, 2016), (Tengor, Gloria, 2016) as well as (Muhtarom, 2018) that states that the price influence on purchase decisions.

\section{The influence of The Quality Of The} Product Against The Decision Of The Purchase Facial Foam Pond's in Semarang

Test hypothesis proves that quality product have a positive and significant impact on purchasing decisions, with the obtained results of $t$ - test of 3,060 and sig. 0,003<0,05. This result can be interpreted as the higher the quality of the product soap facial cleanser Pond's will be more improved consumer purchase decisions. Quality the product is the ability of a product to the displayed function(Ginting, 2012). Products that are able to demonstrate the functions of the the product is capable of providing the required consumer so this makes the consumer interested in making a purchase.

For women consumers each day using a make up then after finished the day or when at home then there is a desire to clean the rest of the makeup so that the face back look clean and for this sabun facial cleanser Pond's provides product Pond's Shake \& Clean which is a cleaning product at once freshener the face of dirt-the dirt, because there is content alcohol although not excessive that can help to clean the dirt effectively so that the rest of the makeup is not look again. This shows the use of the product quality so that consumers will be interested to do purchase.

Assessment high also given regarding the sabun Consumers women also want more attractive conditions on the skin of the face so to meet these needs soap facial cleanser Pond's provides product Flawless White with the Rose Lumiere Serum Rose made of flower extract rose Alphine which helps lock in moisture and disguise dull skin from the inside so that it can reduce dark spots black. With the use of quality products that are able to provide the value of the benefits in accordance with its function as a product that can remove dead skin and reduce dark spots then it is a make consumers are interested to make a purchase sabun facial cleanser Pond's.

Soap cleaning Pond's facial provides product Pond's White Beauty Spot-less Rosy White Daily Facial Foam for consumers who want to disguise a black stain in two weeks, but can 
course consumers get the benefits after using it more than two weeks so this makes the consumers feel with confidence will the ability to give benefits in accordance with the promised time. This condition necessarily need to be a concern for sabun facial cleanser Pond's, that could further increase the content of active Thymo-T Essence and technology Lock + Clear are used for this product to be provide benefits according to the promised time so that it can growing consumer confidence in the product sabun facial cleanser Pond's. This can further enhance the desire of consumers to to make a purchase.

Results the study supports research (Habibah, 2016), (Puspita, Diestutiace Lucky, 2016), (Tengor, Gloria, 2016) as well as Muhtarom and Syahrizal (2018) that states that the product quality influence on purchase decisions.

The influence of Product Design Against The Decision Of The Purchase Facial Foam Pond's in Semarang

Test hypothesis proves that design product have a positive and significant impact on purchasing decisions, with the obtained results of $\mathrm{t}$ - test of 2,199 and sig. 0,030<0,05. These results can be interpreted more and better product design soap facial cleanser Pond's will be more improved consumer purchase decisions. Design product is the totality of features affect the look, feel, and functionality of the product based on the needs of consumers (Kotler, 2014). Design attractive products will be able to improve selfconfidence the consumer in using the product, in addition with the design practical, so easy to carry anywhere then it will give value add for the consumer. This makes the design of the product can influence consumers to make a purchase.

Packaging soap facial cleanser Pond's use a tube light and also there is a small size, which is 50 grams so easy to put into a pocket or bag so that it can carry anywhere and used at any time. It this shows the design soap facial cleanser Pond's have more advantages in terms of practical packaging so that consumers are interested to make a purchase.

Based on from the assessment of the consumer hence to design need to be made with the model packaging is interesting as the use tube packaging it contains a pump of the foam so that the consumer press the top of the bottle then the package contents will come out without having to open the the lid of the bottle so easy to use. This can be add to the appeal of consumers to make a purchase. Other factors that need to be improved to design that consider to make the contents of the packaging with a more interesting color such as colored nodes in order to give the natural impression so that it can add to the interest of the consumer to make a purchase soap facial cleanser Pond's.

Results the study supports research (Erviana, 2014), (Martini, 2015), (Tengor, Gloria, 2016) as well as(Ansah, 2017) that states that the design of the product influence the buying decision.

The influence of The Image Of The Brand Against Purchase Decision Facial Foam Pond's in Semarang

Test hypothesis proves that image brand have a positive and significant impact on purchasing decisions, with the obtained results 
of $\mathrm{t}$ - test of 2,528 and sig. 0,013<0,05. This result can be interpreted as the higher the brand image soap facial cleanser Pond's will be more improved consumer purchase decisions. Image brand is the perception and attitude of consumers towards the brand based on what received and perceived by the consumers(Peter, 2013). Consumers who feel positive things when using a product as tools used to meet the needs and have other advantages such as strong or durable and no service complaints after the use of the services of the manufacturer then the consumer will give a good perception towards the image of the product and this will make consumers will prefer to use products that have the image of the good.

Factors this is affected because sabun cleaning the face of the brand Pond's using the brand name that is simple so it is easily memorized and be one of the products that are heavily promoted in various media like television, which shows they have the desire to be product soap facial cleanser that compete and excel with the various products vary, so this makes consumers easily remember sabun cleaning the face of the brand Pond's and raises the desire to make a purchase because they has the quality to compete with other products.

Based on from the perception given by the consumer is seen that the consumer give you lowest valuation on the sabun cleaning the face of the brand Pond's easy to remember. This can be based on because sabun cleaning the face of the brand Pond's using a variety of foreign names in different variants of its products such as beauty white clay foam and instabright tone up cream so consumers sometimes forget when to use product variants 've ever used because it uses unfamiliar terms.
On the basis of this then you should sabun cleaning the face of the brand Pond's using terms that are more common or easy to remember for each variants such as the use of bahasa Indonesia to further strengthen the image as a product that is intended for consumers in Indonesia, so this will add to the desire of consumers to make a purchase.

Results the study supports research (Erviana, 2014) as well as (Ansah, 2017) that states that the brand image influence on purchase decisions.

\section{Conclusion}

Based on the results of the research that has been done on the influence of price, quality, design products and brand image on purchase decisions consumer soap facial cleanser Pond's in Semarang, then it can be drawn the following conclusion:

1. Test hypothesis proves that prices have a positive and significant to the purchasing decision. This result can be concluded the offer price soap facial cleanser Pond's tools it will increase the consumer purchase decision.

2. Test hypothesis proves that the quality of product of influential positive and significant to the purchasing decision. This result can be concluded the increase of the quality of the product soap cleanser face Pond's then it will increase purchase decisions consumers.

3. Test hypothesis proves that the product design has positive and significant to the purchasing decision. This result can be inferred the existence of the design product soap facial cleanser Pond's the more attractive it will increase the purchasing decision consumers. 
4. Test hypothesis proves that brand image has positive and significant to the purchasing decision. This result can be concluded the increase of the image of the brand soap facial cleanser Pond's then it will increase the consumer purchase decision.

\section{Recommendation}

1. Quality the product becomes variable the biggest influence purchase decisions. Sebaiknya sabun facial cleanser Pond's add a formula that can help in speeding up the black blemishes such as extract Lemon, so that it can benefit blemishes black in two weeks as promised.

2. Image brand be variable the second influence purchase decisions. Sabun facial cleanser Pond's preferably more often publish the name of each variant of the products sold in a variety of the place which often becomes the place of purchase of consumers, such as by pasting the name of the product variants clear solution facial crub, deep whitening facial foam, white beauty cleansing milk in display that there is a self, so that when the consumer already come and forget with a variant of the product to be purchased then it can be read it on a poster tacked on the display.

3. Design product be variable the third influence purchase decisions. Sabun facial cleanser Pond's need to make a more interesting color such as transparent color in order to give the impression of a natural so it can be more interesting the desire of consumers to make a purchase sabun facial cleanser Pond's.
4. Price be variable the smallest that affect the purchase decision. Preferably sabun facial cleanser Pond's offers more affordable prices as cooperation with the outlet or supermarket that is every voting member shopping in outlet or self-service if buy product'sabun facial cleanser Pond's will directly be given the discounted price so get price more affordable if you become a member.

5. Variable analyzed influence on purchase decisions Pond's facial foam labeled halal in this study, namely price, quality, product design and brand image. It this is caused by the limitations time research, so there are still variables other that affect the purchase decision and not included in the this study. In addition to adding variables, we recommend for further research can add consumer respondents product facial foam labeled halal other (not only consumers of the brand Pond's).

\section{References}

Achidah, Nur, M. M. W. dan L. B. H. (2016). "Pengaruh Promosi, Harga, Dan Desain Terhadap Keputusan Pembelian Sepeda Motor Mio GT (Study Empiris Pada Produk Yamaha Mio GT Di Weleri-Kendal). 2(2), 1-17.

Ansah, A. (2017). Pengaruh Desain Produk, Promosi, dan Citra Merek Terhadap Keputusan Pembelian. Jurnal Amwaluna, 1(2), 178-189.

Arikunto, S. (2013). Prosedur Penelitian Suatu Pendekatan Praktik-Revisi ke X. In Prosedur Penelitian Suatu Pendekatan Praktik-Revisi ke X. Rineka Cipta. 
Buchari Alma. (2013). Manajemen Pemasaran dan Pemasaran Jasa. CV Alfabeta.

Daryanto. (2013). Sari Kuliah Manajemen Pemasaran (2nd ed.). PT. Sarana Tutorial Nurani Sejahtera.

Erviana, A. dan D. S. S. (2014). Analisis Pengaruh Desain Kemasan dan Citra Merek Terhadap Keputusan Pembelian Produk Bedak Saripohatji Di Bandung. Jurnal Ilmiah Magister Manajemen UNIKOM, 3(1), 22-29.

Fataron, Z. A., \& Rohmah, H. (2020). Effect Analysis of Trust, Ease, Information Quality, Halal Product on Online Purchase Decision of 2016-2018 Batch Students of Islamic Economics Study Program in UIN Walisongo at Shopee Marketplace. Journal of Digital Marketing and Halal Industry, 1(1), 1. https://doi.org/10.21580/jdmhi.2019.1. 1.4772

Ghozali, I. (2012). Aplikasi Analisis Multivariat dengan Program IBM SPSS 20 (Edisi keenam). Semarang: Universitas Diponegoro. Metode Penelitian Bisnis.

Ginting, N. F. H. (2012). Manajemen Pemasaran (2nd ed.). Yrama Widya.

Habibah, U. dan S. (2016). Pengaruh Kualitas Produk dan Harga Terhadap Keputusan Pembelian Produk Kosmetik Wardah Di Kota Bangkalan Madura. Jurnal Ekonomi Dan Bisnis, 1(1), 31-48. https://doi.org/10.1017/CBO97811074 15324.004

Imelda, Sri, H. H. dan R. (2016). "Pengaruh Bauran Pemasaran Terhadap Keputusan Pembelian Mobil Toyota Pada CV Sentral Motor Banjarmasin. Jurnal
INTEKNA, 16(1), 69-76. https://doi.org/10.5151/cidi2017-060

Kotler, P. dan K. L. K. (2014). Manajemen Pemasaran. Erlangga.

Martini, T. (2015). Analisis Pengaruh Harga, Kualitas Produk dan Desain terhadap Keputusan Pembelian Kendaraan Bermotor Merek Honda Jenis Skutermatic. Jurnal Penelitian, 9(1), 113132.

https://doi.org/10.1017/CBO97811074 15324.004

Muhtarom, A. dan M. T. S. (2018). Pengaruh Kualitas Produk dan Harga Terhadap Keputusan Pembelian Rokok Surya (Studi Kasus Pada Konsumen Rokok Surya Di UNISLA). III(1), 615-621.

Munggaran, A. P. dan E. A. (2015). Pengaruh Endorser Credibility Terhadap Minat Beli Konsumen”. E-Proceeding of Management, 2(3), 2691-2698. https://doi.org/10.1145/3132847.3132 886

Paul, J., \& Olson, J. C. (2013). Perilaku Konsumen dan Strategi Pemasaran (9th ed.). Salemba Empat.

Peter, J. P. dan J. C. O. (2013). Perilaku Konsumen dan Strategi Pemasaran (9th ed.). Salemba Empat.

Puspita, Diestutiace Lucky, E. Y. dan S. (2016). Pengaruh Kualitas Produk Dan Word Of Mouth Terhadap Keputusan Pembelian (Survei Kepada Konsumen Charles \& Keith di Tunjungan Plaza Surabaya). Jurnal Administrasi Dan Bisnis (JAB), 34(1), 79-85. https://doi.org/10.1017/CBO97811074 15324.004 
Siregar, syofian. (2013). Metode Penelitian Kuantitatif: Dilengkapi Perhitungan Manual $\mathscr{E}$ SPSS (1st ed.). Kencana prenata Media Grup.

Suryani, T. (2013). Perilaku Konsumen di Era Internet Implikasinya pada Strategi Pemasaran (Cetakan I). Graha Ilmu.

Tarigan, E. D. S. (2016). Pengaruh Gaya Hidup, Label Halal Dan Harga Terhadap Keputusan Pembelian Kosmetik Wardah Pada Mahasiswa Program Studi Manajemen Fakultas Ekonomi Universitas Medan Area Medan. Jurnal Konsep Bisnis Dan Manajemen, 3(1), 4761.

Tengor, Gloria, L. K. dan S. L. (2016). Pengaruh Merek, Desain Dan Kualitas Produk Terhadap Keputusan Pembelian Iphone Studi Kasus Pada Mahasiswa STIE Eben Haezar Manado. Jurnal Berkala Ilmiah Efisiensi, 16(4), 367-375.

Tjiptono, F. (2015). Strategi Pemasaran (4th ed.). Andi.

Widiyono dan Mukhaer Pakkanna. (2013). Pengantar Bisnis: Respon terhadap Dinamika Global. Mitra Wacana Media. 